УдК 330.341 .1

\title{
ІННОВАЦІЙНІ МЕТОДИ ТА ТЕХНОЛОГІЇ УПРАВЛІННЯ ПІДПРИЄМСТВОМ В УМОВАХ ЕКОНОМІКИ MIНIMАЛЬНОГО КОНТАКТУ
}

\section{INNOVATIVE METHODS AND TECHNOLOGIES OF ENTERPRISE MANAGEMENT IN THE LOW TOUCH ECONOMY}

\author{
Гадецька Зоя Митрофранівна \\ кандидат технічних наук, доцент, \\ Черкаський національний університет імені Богдана Хмельницького \\ ORCID: https://orcid.org/0000-0002-9994-8488 \\ Кузьмінський Віталій Віталійович \\ магістрант, \\ Черкаський національний університет імені Богдана Хмельницького \\ ORCID: https://orcid.org/0000-0002-8634-1345
}

Gadetska Zoya, Kuzminsky Vitaliy

Cherkassy Bogdan Khmelnitsky National University

\begin{abstract}
Стаття присвячена актуальним питанням впровадження нових інноваційних методів та технологій управління в умовах економіки мінімального контакту. Економіка мінімального контакту - це новий феномен ведення бізнесу, для якого характерно уповільнення попиту, скорочення фрізичного взаємодії між споживачами і постачальниками товарів і послуг. Тому для стабільного економічного розвитку України в умовах економіки мінімального контакту та у контексті антикризового управління підприємством стала очевидна необхідність появи нових орієнтирів і нових інноваційних методів та технологій управління підприємством для більш швидкого продажу товарів та послуг, віддаленої роботи персоналу та спілкування із клієнтами. Уже зараз чимала кількість компаній реагує на виникаючі потреби, ретельно досліджують свої бізнес-моделі, шукають шляхи оптимізації бізнес-процесів. Розглянемо вирішення цих питань на прикладі рієлторської діяльності, яка останнім часом переживає значні зміни, зокрема у соері законодавства. Тому виникає необхідність суттєвих змін в управлінні рієлторськими компаніями. Авторами запропоновано запроваджувати в роботу рієлторських компаній технології бенчмаркінгу, аутстафінгу, цифрові технології та застосувати хмарні CRM системи.

Ключові слова: економіка мінімального контакту, інноваційні методи та технології управління, бенчмаркінг, хмарні CRM-системи.
\end{abstract}

Статья посвящена актуальным вопросам внедрения новых инновационных методов и технологий управления в условиях экономики минимального контакта. Экономика минимального контакта - это новый френомен ведения бизнеса, для которого характерно замедление спроса, сокращение фризического взаимодействия между потребителями и поставщиками товаров и услуг. Поэтому для стабильного экономического развития Украины в условиях экономики минимального контакта и в контексте антикризисного управления предприятием стала очевидна необходимость появления новых ориентиров и новых инновационных методов и технологий управления предприятием для более быстрой продажи товаров и услуг, удаленной работы персонала и общения с клиентами. Уже сейчас немалое количество компаний реагирует на возникающие новые условия работы, тщательно исследуют свои бизнес-модели, ищут пути оптимизации бизнес-процессов. Рассмотрим решение этих вопросов на примере риэлторской деятельности, которая в последнее время переживает значительные изменения, в частности в сфере законодательства. Поэтому возникает необходимость существенных изменений в управлении риэлторскими компаниями. Авторами предложено внедрять в работу риэлторських компаний технологии бенчмаркинга, аутстаффиинг, цифровые технологии и применять облачные CRM системы.

Ключевые слова: экономика минимального контакта, инновационные методы и технологии управления, бенчмаркинг, облачные CRM-системы. 
The article is devoted to topical issues of introduction of new innovative methods and technologies of management in the conditions of Law Touch Economy. Law Touch Economy - is a new phenomenon of doing business, which is characterized by a slowdown in demand, reducing the physical interaction between consumers and suppliers of goods and services. Therefore, for the stable economic development of Ukraine in Law Touch Economy, it became obvious the need for new innovative methods and technologies of enterprise management for faster sales of goods and services, remote work of staff and communication with customers. Consider the solution of these issues on the example of real estate activities, which has recently undergone significant changes, in particular in the field of legislation. Therefore, there is a need for significant changes in the management of real estate companies. The authors propose to introduce benchmarking, outstaffing, digital technologies and use of cloud CRM systems in the work of real estate companies. The study of the software market allowed to offer a CRM system - Bitrix 24 on the basis of cloud technologies for the work of real estate companies. Bitrix24 is designed to flexibly manage the company's structure and provide access from anywhere in the world where the Internet is connected. Also, the Realtsoft CRM cloud system has been proposed for implementation. The Realtsoft system is connected to the real estate database of Ukraine and allows you to quickly search for any object in real time. An equally important area in the work of real estate companies is the issue of real estate valuation. Under the new legislation, real estate valuation is mandatory and is carried out automatically through an automated electronic platform. However, if the owner does not agree with the automatically calculated value of the property, then the appraisal is conducted by a real estate appraiser, who can be hired using outstaffing technology. The study showed that continuous and significant changes in technology, markets and needs are forcing real estate agencies to continuously change strategy and tactics to survive in today's Law Touch Economy.

Keywords: Law Touch Economy, CRM systems, cloud technologies, benchmarking, outstaffing.

Постановка проблеми. Для стабільного економічного розвитку України в умовах економіки мінімального контакту (Law Touch Economy) та у контексті антикризового управління підприємством стала очевидна необхідність появи нових орієнтирів і нових інноваційних методів та технологій управління, цифрових технологій, хмарного програмного забезпечення. Виклик сьогодення - почати змінюватись.

Крім того, однією 3 ключових проблем в господарській діяльності підприємств стала неефективність існуючих методів управління. Тому так важливо, впровадження в діяльність підприємств нових більш ефрективних та інноваційних методів та технологій управління підприємством, зокрема он-лайн хмарних та цифрових технологій для більш швидкого продажу товарів та послуг, віддаленої роботи персоналу та спілкування із клієнтами. Скорочення фрізичного взаємодії між споживачами і постачальниками товарів і послуг в умовах економіки мінімального контакту - важливе обмеження і одночасно можливість для ведення бізнесу в нових умовах.

Тому так актуальна тема дослідження, яка присвячена питанням впровадження нових методів управління підприємством в умовах економіки мінімального контакту.

Аналіз останніх досліджень і публікацій. Серед наукових робіт вчених, які досліджували питання впровадження інноваційних методів і технологій управління підприємством, слід відмітити праці О.В. Христенка [1], Г.М. Пурія [2], О.В. Ольшанського [3] та ін.
Виділення невирішених раніше частин загальної проблеми. Опрацювання праць вище вказаних науковців дозволило максимально змістовно підійти до дослідження поставленого наукового завдання, а також виявити питання, що залишаються невирішеними. Зокрема, гостро постає це питання в умовах сьогодення, в нових складних умовах ведення бізнесу - в умовах економіки мінімального контакту,

Формулювання цілей статті. Метою даної статті $€$ впровадження сучасних інноваційних методів та технологій управління підприємством в нових умовах ведення бізнесу умовах економіки мінімального контакту

Виклад основного матеріалу. Економіка мінімального контакту (Low touch economy) це новий феномен ведення бізнесу. Цей термін вперше був започаткований американською консалтинговою компанією Board of Innovation, яка у листопаді 2020 року підготувала аналітичний звіт: як компаніям відновлюватися й рости в період пандемії коронавірусу. Ключові характеристики Low touch economy - уповільнення попиту, фрормування нових страхів і побоювань, споживчий ескапізм. Low touch economy визначатиме наше життя мінімум наступні два роки, приблизно стільки часу знадобиться, щоб приборкати COVID-19. За цей період будуть активно змінюватися споживчі звички, зміниться баланс між роботою та особистим життям, зросте попит на електронну торгівлю і логістику та iн. [1]. Так, вже зріс попит на он-лайн закази та покупки, скорочуються візити в ресторани 
та розважальні заклади, використання громадського транспорту. Для одних компаній робота в умовах економіки мінімального контакту може стати точкою для зростання, для інших компаній - помітною перешкодою для ведення бізнесу.

Уже зараз чимала кількість компаній реагує на виникаючі потреби, ретельно досліджують свої бізнес-моделі, шукають шляхи оптимізації бізнес-процесів. Розглянемо вирішення цих питань на прикладі рієлторської діяльності. Останнім часом ця сорера переживає значні зміни. Так майже рік в Україні розроблявся законопроект, що призваний оновити систему оренди, купівлі та продажу нерухомості. Як результат, у липні 2020 прийнятий в першому читанні Закон «Про рієлторську діяльність». Запропоновані в цьому законі зміни здатні кардинально змінити структуру всієї цієї індустрії. І рієлторські послуги сорера, що в першу чергу відчує найбільший вплив цього законопроекту. Новий закопроект передбачає, що всі операції із нерухомістю тепер повинні проводитись із залученням посередника - рієлтора. Новий законопроект передбачає також введення нової посади «брокера з нерухомості» із свідоцтвом [2].

У зв'язку з цим, виникає необхідність суттєвих змін в управлінні рієлторськими компаніями та впровадження в їх роботу інноваційних методів та технологій управління, запровадження сучасних методик моделювання [3] та оптимізації бізнес-процесів підприємств. Оптимізація бізнес-процесів - це комплекс заходів, спрямований на виявлення та ліквідацію вузьких і проблемних місць. В даний час існує декілька інноваційних підходів до управління та оптимізації бізнес-процесів: впровадження систем менеджменту якості, бенчмаркінг бізнес-процесів, методологія безперервного вдосконалення бізнес-процесів BPI (Business Process Improvement), реінжиніринг бізнес-процесів, грінфрілд.

Серед них для оптимізації бізнес-процесів особливу увагу хотілося б звернути на технологію бенчмаркінгу бізнес-процесів. Бенчмаркінг - це технологія, спрямована на поліпшення бізнесу або послуги. Бенчмаркінг - це підхід до аналізу фрінансових і нефрінансових показників, основною метою якого $є$ забезпечення сталого розвитку та безперервного вдосконалення. Найбільш релевантні показники, визначені як запорука стратегічного успіху, порівнюються 3 аналогічними показниками інших компаній, що визнані лідерами в тій чи іншій сорері діяльності. Наслідками застосу- вання бенчмаркінгу стають докорінні покращення, але тільки в тому випадку, якщо перед тим, як почати, зрозуміти власні процеси, які описані у вигляді бізнес-процесів. Бенчмаркінг $€$ надзвичайно корисним інструментом, особливо в ситуації, коли необхідно переглянути внутрішню ефективність діяльності компанії та визначити нові пріоритети.

Бенчмаркінг $€$ зовнішній - відстежування останніх досягнень і трендів на ринку, вивчення прикладів найуспішніших стратегій і моделей ведення бізнесу та пошук шляхів застосування отриманих знань для поліпшення власних операційних процесів. Використання цього підходу допомагає вчасно виявити негативні тенденції всередині компанії, наголосити на необхідності здійснення змін, звернути увагу на свої сильні та слабкі сторони порівняно з прямими конкурентами, а також фрірмами з інших галузей. Також розрізняють внутрішній бенчмаркінг - зіставлення організаційних одиниць, відділів, видів послуг однієї й тієї самої організації. Це актуально для великих компаній або тих, що представлені в різних регіонах.

Для реалізації моделі бенчмаркінгу необхідно обрати компанію, що є лідером в цій галузі. Для цього можна використати матеріали щорічних конкурсів та премій, як елементів бенчмаркінгу, які дають змогу порівнювати компанії, фрормуючи певний рейтинг їхнього розвитку, конкурентоспроможності тощо. Багато підприємств після участі у конкурсах та преміюванні знайшли нові можливості використання досконаліших моделей управління бізнес-процесами, а моделі премій зайняли гідне місце в арсеналі оптимізації бізнес-процесів. Так для рієлторських компаній, можна запропонувати використовувати щорічні рейтинги «Найкращі рієлторські компанії України» [4]. В цьому рейтингу компанії оцінюються за декількома критеріями: профресіоналізм; якість роботи з клієнтами; безпека угод та даних; застосування нових технологій в роботі.

Згідно статистичних даних при реалізації технології бенчмаркінг та зважаючи на досвід використання, цей підхід доцільно обирати для оптимізації до 20-30\% основних бізнеспроцесів компанії. Тому можна також запропонувати інший метод оптимізації діяльності, а саме перепроектування процесів (концентроване покращення), що акцентує увагу команди на безперервне вдосконалення існуючих бізнес-процесів. Використання даного підходу може бути коректним приблизно для 70-90\% основних бізнес-процесів. Такий під- 
хід доцільно використовувати, якщо покращення показників діяльності підприємства на 70-80\% зможе забезпечити йому конкурентні переваги. Це можливо завдяки застосуванню сучасних програмних засобів та інсрормаційно-комунікаційних технологій.

Впровадження інсрормаційних технологій в роботу рієлторських компаній дозволить підвищити ефрективності їх роботи, покращити якість та оперативності надання послуг. Для цього пропонуються для впровадження хмарні CRM-системи.

CRM-системи - це прикладне програмне забезпечення для підприємств, що допомагає більш ефективно взаємодіяти з клієнтами, упорядковувати, планувати та керувати роботою 3 ними. Однак для того, аби ці системи працювали стабільно і швидко, їх впроваджують на базі хмарних технологій. В Україні CRM-системи лише на шляху набуття популярності. Звісно, наздоганяти за кількістю підприємств, що користуються CRM-системами, приміром, США, нам ще довго: там цей показник складає близько 90\%. Хмарні технології надають CRM-системам значні переваги, а саме:

- стабільність і швидка робота програмного забезпечення;

- надійний захист даних. Уся інфрормація зберігається за межами компанії, а саме - на віртуальних серверах;

- скорочення витрат. Із хмарами не потрібно витрачатися на закупівлю потужного IT-обладнання, його оновлення та заміну:

- мобільність. Працювати із CRM-системою можна будь-де та будь-коли, а для доступу до програмного забезпечення не потрібне надпотужне обладнання. Тож підключитися до робочого середовища можна 3 будь-якого куточка світу зі смарторона або планшета, головне - це наявність-інтернет доступу [5].

Авторами статі був проведений огляд та аналіз ринку популярних CRM-систем. Найпопулярнішими CRM-системами на українському сегменті $€$ :

- Bitrix24 - хмарна CRM, допомагає малому та середньому бізнесу управляти продажами, забезпечує всі комунікації із клієнтами та автоматизує продажі.

- Worksection - CRM-сервіс для систематизації проектних даних: завдань, виконавців, термінів, документації тощо.

- Мегаплан - CRM-система для малого та середнього бізнесу й підрозділів великих підприємств. Призначена для управління бізнесом та збільшення продажів. Мегаплан доступний і як хмарна, і як коробочна система.
- Sales Creatio - хмарна CRM-система для профресійного управління продажами i пов'язаними з ними бізнес-процесами.

- Microsoft Dynamics CRM допомагає організувати продажі, послуги та маркетинг.

- Pipedrive - це хмарне рішення для управління воронкою продажів. Надає інструменти для моніторингу індивідуальних і командних рівнів, аналізу інфрормації про контракти і створення візуалізованих звітів.

- KeepinCRM - онлайн-система для оптимізації роботи малого та середнього бізнесу з налаштуванням до специсріки різних бізнесмоделей та ін. [6].

Для впровадження в роботу рієлторських компаній була запропонована перша в рейтингу CRM-система - Бітрікс24 на базі хмарних технологій. Вона представляє собою онлайнсервіс та призначена для гнучкого управління структурою компанії та надання доступу до нього з будь-якої точки світу, де $\epsilon$ інтернетпокриття. Це хмарне програмне забезпечення ідеально підходить для підприємств, кількість співробітників яких менше 100. Вся інфрормація розміщується на серверах постачальника, який забезпечує ії безпеку і збереження. Робота з CRM ведеться в браузері і не потребує встановлення будь-яких додатків. Використовувати платорорму можна одразу після реєстрації та оплати обраного тарифру. Але команда до 12 людей може користуватися базовими фрункціями безкоштовно. Можливості хмарної версії CRM-системи Бітрікс24: управління лідами та контрактами; виставлення рахунків; управління проектами та завданнями; автоматизація бізнес-процесів; налаштування роботів, тригерних листів, смс та реклами безпосередньо із CRM; вбудована IP-телесронія та інтеграція з поштою; підключення відкритих ліній (налаштування Facebook, Instagram, інших месенджерів для чату в Бітрікс24); налаштування планів продажів і звітів; друк і відправлення документів з CRM; створення сайтів, лендінгів із вбудованою CRM та ін.

Бітрікс24 дозволяє швидко розпочати роботу: за декілька хвилин користувач може настроїти власний портал, запросити колег, виставити завдання, і для цього тільки необхідні підключення до Інтернет та створення бітріксу для компанії.

Крім вже запропонованої до впровадження програми Бітрікс24 для автоматизації Front офрісних технологій пропонується також ще сучасне програмне забезпечення для Backофрісу рієлторських компаній. Це програмне забезпечення для автоматизації внутрішніх 
бізнес-процесів, що надає агентам 3 нерухомості все, від інструментів генерації угод до звітності; дозволяє заощадити час персоналу компанії та управляти їх завданнями.

Проведене дослідження ринку цього сегменту ринку програмного забезпечення дозволило виділити низку програмних засобів для роботи рієлторських компаній, а саме: Realtsoft CRM, Freshsales, Yaware.Timetracker, Area Pulse, Trello, Getcontact та ін.

Для впровадження обрано хмарну систему для агентств нерухомості Realtsoft CRM. Ця CRM систем розроблена компанією Realtsoft World у співпраці з практикуючими ріелторами. Система Realtsoft підключена до бази даних нерухомості України та дозволяє швидко здійснювати пошук будь-якого об'єкта в режимі реального часу. Для покращення обслуговування клієнтів в програмі ведеться клієнтська база даних та для зручності віддаленої дистанційної роботи створена база даних всіх співробітників агентства з різними правами доступу до інформації в режимі реального часу з будь-якого гаджету. Для перегляду та контрою дій своїх співробітників системою передбачений журнал дій користувачів.

Для оперативного управління компанією в програмі передбачений модуль «Задачі» та вбудована зручна аналітика і статистика по ключовим аспектах: нові об'єкти і клієнти, успішність агентів, дані по операціях та ін.

Не менш важливим напрямом рієлторської діяльності $€$ питання оцінки вартості об'єктів нерухомості. Оцінка нерухомості в Україні це процедура, яка дозволяє визначити (розрахувати) середню ринкову вартість нерухомого майна (квартири, будинку, земельної ділянки тощо). нерухомості.

За новим законодавством оцінка вартості нерухомого майна є обов'язковою і визначення оціночної вартості об'єкта нерухомості проводиться автоматично через автоматизований електронний майданчик «Реєстр оцінки». Але, якщо власник не погоджується 3 автоматично розрахованою вартістю нерухомості, тоді оцінку проводить оцінщик нерухомості.

Для залучення оцінювача із Державного реєстра оцінювачів пропонується авторами застосовувати сучасну технологію найму співробітників - аутстафрінг (з англ. outstaffing діяльність із надання персоналу). Найнятий на основі аутстафрінгу оцінювач, що входиться до Державного реєстру оцінювачів, може надавати консультації на ринку нерухомості щодо оцінки вартості конкретного нерухомого майна та за необхідністю визначати вартість на окремі будівлі та приміщення.

Алгоритми реалізації методик оцінювання вартості нерухомості вже закладені в принципі срункціонування сучасних програмних засобів. Аналіз ринку програмних засобів для оцінки нерухомості дозволив виділити та розглянуті наступні програмні засоби: веб-система он-лайн замовлень оцінок власності компанії Turbo BPO; Cepвic Pam's Vas Real estate Virtual Assistant Services; Matrix, Itech; CMA, Comparative Market analysis; система MLS BPO та ін. Але більшість з цих програмних засобів - англомовні. Тому на українському ринку програмного забезпечення для оцінювання нерухомості можна рекомендувати для оцінки майна, на основі українського законодавства, програму «Оцінювач».

Висновки. Проведене дослідження показало, що безперервні та досить істотні зміни у технологіях, ринках збуту і потребах змушують агентства 3 нерухомості безперервно перебудовувати свою стратегію і тактику, прагнучи вижити в сучасних умовах економіки мінімального контакту. Успіх компанії сьогодні напряму залежить від його спроможності трансформувати свою бізнесову модель у сучасних умовах. Рішенням даної проблеми є зміна базових принципів організації діяльності та проведення оптимізації управління підприємством на основі розглянутих та запропонованих інноваційних методів та технологій управління для забезпечення стійкого і динамічного фрункціонування та розвитку цього бізнесу.

\section{СПИСОК ВИКОРИСТАНИХ ДЖЕРЕЛ:}

1. Христенко О.В., Боєв М.І. Управління впровадженням інноваційних технологій на будівельних підприємствах. Економіка і регіон. 2017. № 6. С. 118-124. URL: http://nbuv.gov.ua/UJRN/econrig_2017_6_20 (дата звернення: 10.12.2020).

2. Пурій Г.М. Інсрормаційні системи і технології в управлінні діяльністю підприємства. Електронний журнал «Есрективна економіка». 2019. № 6. URL: http://www.economy.nayka.com.ua/?op=1\&z=7127 (дата звернення: 10.12.2020). doi: 10.32702/2307-2105-2019.6.56

3. Ольшанський О.В. Аналіз методів удосконалення бізнес-процесів підприємств торгівлі. Держава та регіони. Серія : Економіка та підприємництво. 2019. № 2. С. 104-110. URL: http://nbuv.gov.ua/UJRN/ drep_2019_2_20 (дата звернення: 10.12.2020). 
4. Что такое Low Touch Economy? URL: https://fcproject.ru/timeline-low-touch-economy (дата звернення: 10.12.2020).

5. Брикайло Ю. Брокерська діяльність у сфері нерухомості. 2020. URL: https://dreamdim.ua/uk/brokerskadiyalnist-u-sferi-neruhomosti (дата звернення: 10.12.2020).

6. Гадецька 3.М., Холопова М.О. Моделювання бізнес-процесів діяльності підприємства. Електронний журнал «Ефективна економіка». 2016. № 5. URL: http://www.economy.nayka.com.ua/?op=1\&z=4950 (дата звернення: 10.12.2020).

7. Пост-реліз VIII Національного фроруму «Нерухомість України як сегмент економіки держави. Європейський напрям розвитку», 30 листопада - 12 грудня 2019 p. URL: https://www.ukrainerealt.com.ua/?article=182 (дата звернення: 10.12.2020).

8. СRM-системи у хмарі. URL: https://tucha.ua/uk/solutions/crm-sistemi-u-khmari (дата звернення: 10.12.2020).

9. Клюйко Г. Огляд двадцятки найкращих CRM-систем для бізнесу. URL: https://esputnik.com/uk/blog/ oglyad-dvadcyatki-najkrashih-crm-sistem-dlya-biznesu (дата звернення: 10.12.2020).

\section{REFERENCES:}

1. Khristenko O.V., Boev M.I. (2017) Upravlinnia vprovadzhenniam innovatsiinykh tekhnolohii na budivelnykh pidpryiemstvakh [Management of implementation of innovative technologies at construction enterprises]. Ekonomika i rehion, no. 6. Available at: http://nbuv.gov.ua/UJRN/econrig_2017_6_20 (accessed 10 December 2020).

2. Puriy H.M. (2019) Informatsiini systemy i tekhnolohiï v upravlinni diialnistiu pidpryiemstva [Information systems and technologies in the management of the enterprise activity]. Efektyvna ekonomika [Online], no. 6. Available at: http://www.economy.nayka.com.ua/?op=1\&z=7127 (accessed 10 December 2020). doi: 10.32702/2307-2105-2 019.6 .56

3. Olshansky O.V. (2019) Analiz metodiv udoskonalennia biznes-protsesiv pidpryiemstv torhivli Information systems and technologies in the management of the enterprise activity [Analysis of methods for improving the business processes of trade enterprises]. Derzhava ta rehiony, no. 2, pp. 104-110. Available at: http://nbuv.gov.ua/UJRN/ drep_2019_2_20 (accessed 10 December 2020).

4. Chto takoe Low Touch Economy? [What is Low Touch Economy?]. Available at: https://fcproject.ru/timelinelow-touch-economy (accessed 10 December 2020).

5. Brikailo Y. (2020). Brokerska diialnist u sferi nerukhomosti [Broker activity in the sphere of non-ruggedness]. Available at: https://dreamdim.ua/uk/brokerska-diyalnist-u-sferi-neruhomosti (accessed 10 December 2020).

6. Gadetska Z.M., Holopova M.O. (2016) Informatsiini systemy i tekhnolohiï v upravlinni diialnistiu pidpryiemstva [Modeling business processes of enterprise]. Efektyvna ekonomika [Online], no. 5. Available at: http://www.economy.nayka.com.ua/?op=1\&z=4950 (accessed 10 December 2020).

7. Post-reliz VIII Natsionalnoho forumu «Nerukhomist Ukrainy yak sehment ekonomiky derzhavy. Yevropeiskyi napriam rozvytku» [Post-release of the VIII National Forum «Real Estate of Ukraine as a segment of the state economy. European direction of development»]. Available at: https://www.ukrainerealt.com.ua/?article=182 (accessed 10 December 2020).

8. CRM-systems in the cloud [CRM-systemy u khmari]. Available at: https://tucha.ua/uk/solutions/crm-sistemi-ukhmari (accessed 10 December 2020).

9. Klyuyko G. (2020) Ohliad dvadtsiatky naikrashchykh CRM-system dlia biznesu [Review of the twenty best CRM-systems for business]. Available at: https://esputnik.com/uk/blog/oglyad-dvadcyatki-najkrashih-crm-sistemdlya-biznesu (accessed 10 December 2020). 